\title{
Synergistic Effect of Metal Soaps and Natural Zeolite on Poly(vinyl chloride) Thermal Stability
}

\author{
Sevdiye Atakul, Devrim Balköse, Semra Ülkü \\ Department of Chemical Engineering, Izmir Institute of Technology, Gulbahce Koyu, Urla-Izmir 35430, Turkey
}

\begin{abstract}
The synergistic effect of metal soaps (zinc stearate and calcium stearate) and/or natural zeolite (clinoptilolite) on PVC thermal stability was investigated. For this purpose, PVC plastisol was prepared by mixing poly(vinyl chloride) (PVC) and dioctyl phthalate (DOP) and stabilized with different amounts of metal soaps and zeolite. Kinetic studies of dehydrochlorination at 140 and $160^{\circ} \mathrm{C}$ were done for unstabilized and stabilized PVC plastigels using 763 PVC Thermomat equipment. The stabilizing effect of zeolite on the increase in the induction period of the sample was considered to result from the absorption of $\mathrm{HCl}$, a property that was thought to reduce the autocatalytic effect of $\mathrm{HCl}$ evolved at the initial stages of dehydrochlorination. Since the induction time of the sample having $0.53 \%$ of zinc stearate and $0.53 \%$ of zeolite was higher than those of the PVC plastigels having only zinc stearate or zeolite, the synergistic effect on thermal stability was observed at low levels of these additives. J. VINYL ADDIT. TECHNOL., 11:47-56, 2005. (c) 2005 Society of Plastics Engineers
\end{abstract}

\section{INTRODUCTION}

The thermal degradation of poly(vinyl chloride) (PVC) has been studied by many researchers [1-4]. The wide applicability of PVC is due to its easy modification by various additives, its chemical resistance, and its low production cost [1]. Most PVC applications require the use of additives, which provide flexibility of processing and different properties to final products. One of the most common PVC compounds is plastisol [2]. PVC plastisols are a suspension of fine particles of PVC emulsion resins in a plasticizer [3]. In general, higher compatibility of the plasticizer with the polymer in a plastisol brings about an easier and faster gelation. Therefore, phthalates are generally used for this purpose $[3,5]$. The major disadvantage of PVC is its thermal instability. The main reaction of the PVC thermal degradation is dehydrochlorination (DHC), which starts at about $100^{\circ} \mathrm{C}$ and is the reason for discoloration, due to the formation of polyene sequences $[1,6,7]$. It is catalyzed by $\mathrm{HCl}$ evolved (autocatalysis), and also promoted by other strong

Correspondence to: Devrim Balköse, e-mail: devrimbalkose@iyte.edu.tr Contract grant sponsor: Technical and Scientific Research Council of Turkey (TÜBİTAK); contract grant number: MİSAG 185. DOI 10.1002/vnl.20035

Published online in Wiley InterScience (www.interscience.wiley.com). (C) 2005 Society of Plastics Engineers acids. So a number of chemicals can be used as stabilizers against these very undesirable degradation processes $[1,8,9]$. The basic principles of stabilization against heat and light were developed between 1930 and 1950, but the search for more effective, less toxic, and environmentally friendly systems has been one of the most important tasks of the PVC industry. The compounds used as heat stabilizers for PVC are lead compounds, organotin compounds, organic stabilizers, compounds of other metals (calcium, zinc, barium, aluminum, and their composites), and inorganic stabilizers (zeolite and hydrotalcite) $[5,9]$. Metal compounds are used to displace the labile chlorine atom in PVC polymer chain by more stable groups and they were considered $\mathrm{HCl}$ scavengers until Frye and Horst demonstrated the esterification reaction with polymer, substituting allylic chlorides $[4,6,8,10]$. Zeolite $5 \mathrm{~A}$ and hydrotalcite are used as acid absorbers in PVC in order to absorb evolved $\mathrm{HCl}$ and other strong acids which catalyzed the dehydrochlorination of PVC $[11,12]$. Natural zeolites such as chabazite and clinoptilolite could be alternative acid absorbers for PVC stabilization.

Thermal stabilization of PVC can be determined by PVC Thermomat equipment. When PVC plastigels are heated in PVC Thermomat in the presence of nitrogen gas, the conductivity of water, through which nitrogen gas is passed, changes with respect to time. The period when the conductivity starts to increase is called induction time, and the period when the conductivity value reaches $50 \mu \mathrm{S} / \mathrm{cm}$ is called stability time. This value is the maximum acceptable level of degradation. Rate of dehydrochlorination can be determined by the conductivity of the solution where the evolved $\mathrm{HCl}$ gas is transferred.

This study aims to investigate the synergistic effect of zinc stearate $\left(\mathrm{ZnSt}_{2}\right)$, calcium stearate $\left(\mathrm{CaSt}_{2}\right)$, and an abundant zeolitic tuff present in Turkey on PVC thermal stability using PVC Thermomat. The kinetic parameters of dehydrochlorination of PVC were determined by heating them at 140 and $160^{\circ} \mathrm{C}$.

\section{EXPERIMENTAL}

\section{Materials}

Poly(vinyl chloride), dioctyl phthalate (DOP), viscobyk 5025 (BYK Chemicals, Wallingford, MA), different 
TABLE 1. Mass \% of additives used to stabilize the PVC plastisols.

Plastisols contain $43 \%$ DOP in mass

\begin{tabular}{|c|c|c|c|}
\hline \multicolumn{2}{|c|}{ Additive mass $\%$} & \multicolumn{2}{|c|}{ Additive mass $\%$} \\
\hline $\mathrm{ZnSt}_{2}$ & Zeolite & $\mathrm{CaSt}_{2}$ & Zeolite \\
\hline- & - & - & - \\
\hline 2.11 & - & 2.11 & - \\
\hline - & 2.11 & - & 2.11 \\
\hline 0.53 & 0.53 & 0.53 & 0.53 \\
\hline 1.05 & 1.05 & 1.05 & 1.05 \\
\hline 1.56 & 1.56 & 1.56 & 1.56 \\
\hline 2.07 & 2.07 & 2.07 & 2.07 \\
\hline
\end{tabular}

amounts of $\mathrm{ZnSt}_{2}, \mathrm{CaSt}_{2}$, and natural zeolite were used to produce PVC plastisol. Plastisol mixtures (composition given in Table 1) were obtained by mixing the additives and PVC plastisol. A typical emulsion type commercial PVC resin (Petvinil P.38/74) was used for plastisol preparation. DOP was used as a plasticizer (Merck, Darmstadt, Germany). Its density is $0.98 \mathrm{~g} / \mathrm{ml}$ and molecular weight is $390.54 \mathrm{~g} / \mathrm{mol}$. The plasticizer content of plastisol was $43 \%$ in mass. $\mathrm{ZnSt}_{2}$ and $\mathrm{CaSt}_{2}$ were produced by a precipitation technique [13]. Zeolitic tuff rich in clinoptilolite mineral from Gördes (Western Anatolia) was used. It was characterized and used after grinding and sieving from a $45 \mu \mathrm{m}$ sieve [14]. The composition of clinoptilolite was $66.36 \%$ $\mathrm{SiO}_{2}, 11.36 \% \mathrm{Al}_{2} \mathrm{O}_{3}, 1.227 \% \mathrm{Fe}_{2} \mathrm{O}_{3}, 3.844 \% \mathrm{~K}_{2} \mathrm{O}, 0.998 \%$ $\mathrm{Na}_{2} \mathrm{O}, 2.344 \% \mathrm{CaO}, 0.420 \% \mathrm{MgO}, 14.22 \% \mathrm{H}_{2} \mathrm{O}$. In addition to zeolitic phase, quartz, cristobalite, and K-feldspar were detected in the X-ray diffraction patterns. The clinoptilolite content was estimated as $80 \%$ [15]. The plastisol composition with zeolitic tuff had a small amount of elements such as iron and potassium, but mainly included aluminum and silicon elements. Additionally, zinc and calcium elements added to the plastisol by means of metal stearates had a higher concentration than the trace amounts of iron and potassium originating from zeolitic tuff. Therefore, the effect of iron and potassium was ignored in this study.

\section{Preparation of PVC Plastisol and PVC Plastigel}

The plastisol was spread onto a piece of cardboard using a 90- $\mu$ film applicator (Sheen 113 N). All plastisol films were gelled for $15 \mathrm{~min}$ in an air-circulating oven (EV 018) at $140^{\circ} \mathrm{C} \pm 3^{\circ} \mathrm{C}$. Since the plasticizer diffused into the particles of PVC resin, the films were gelled and plastigel films were obtained.

\section{Thermal Stability Test}

A thermal stability test was performed using 763 PVC Thermomat. It is equipped with two heating blocks each with four measuring positions. Each block can be individually heated; therefore, two sets of four samples can be measured at two different temperatures or eight samples can be measured at the same temperature. Also, the measurements at the individual measuring positions can be started individually. To validate the accuracy of PVC Thermomat, powder form PVC samples $(0.5 \mathrm{~g})$ were put into eight reaction vessels and tested at the same time. On the other hand, the films were cut into $0.5 \times 0.5 \mathrm{~cm}$ small squares and $0.5 \mathrm{~g}$ of each sample was put into the reaction vessel. The heating blocks of PVC Thermomat were heated to 140 and $160^{\circ} \mathrm{C}$. The reaction vessels that contained PVC plastigel films were placed into the heating blocks. As shown in Fig. 1 , the $\mathrm{HCl}$ formed was taken up by a nitrogen gas stream and transferred into the measuring vessels. The deionized water absorbed $\mathrm{HCl}$ gas and the conductivity of the solution changed with respect to time. Therefore, the decomposition process was monitored by measuring the conductivity of aqueous $\mathrm{HCl}$ solution.

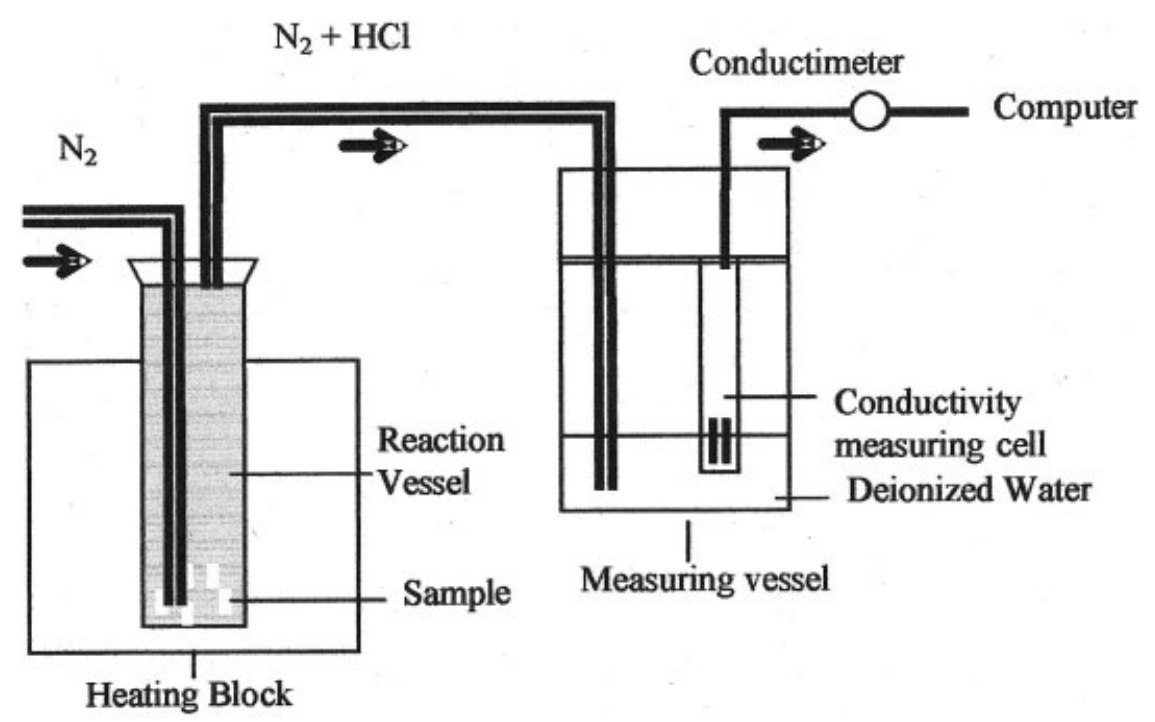

FIG. 1. The measuring arrangement of 763 PVC Thermomat. 


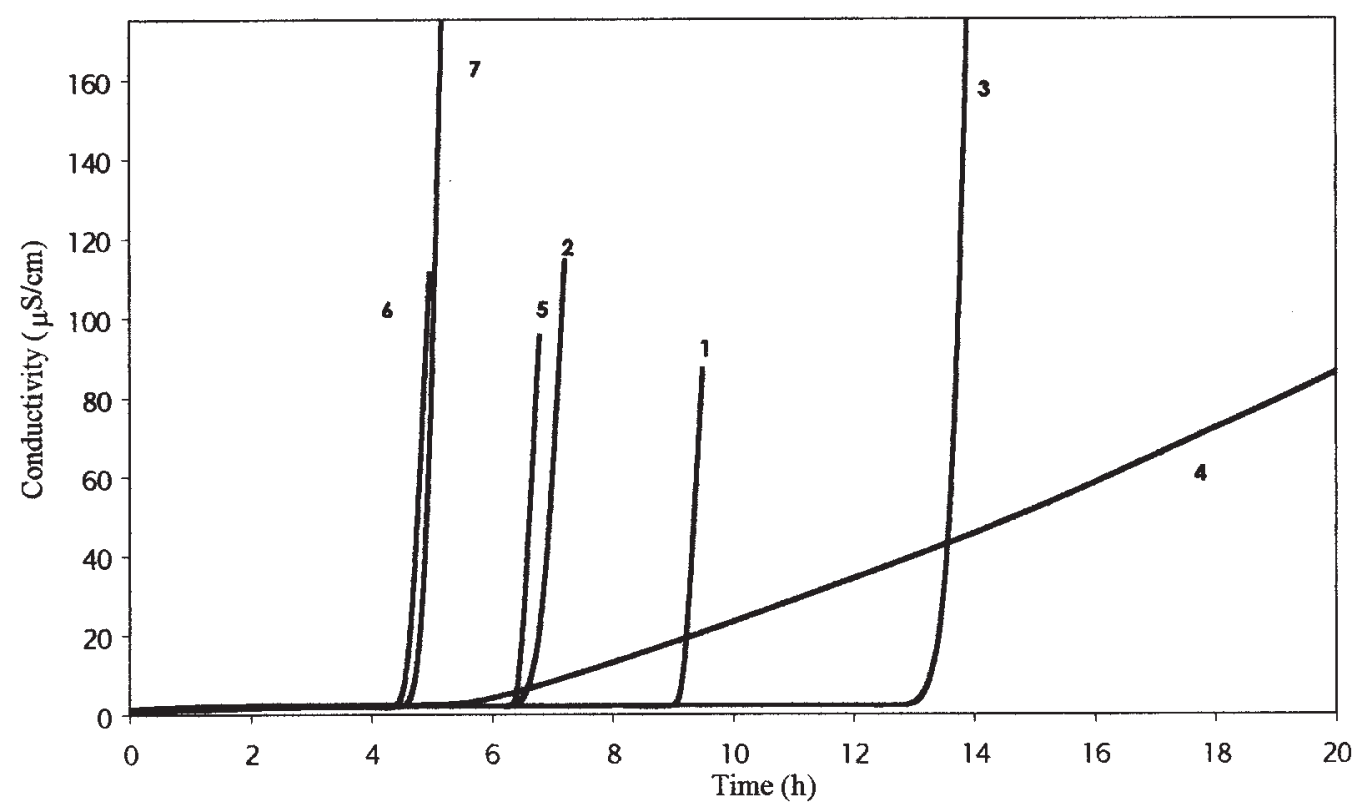

FIG. 2. The change of conductivity of aqueous solution with respect to time at $140{ }^{\circ} \mathrm{C}$ for PVC plastigels stabilized with $\mathrm{ZnSt}_{2}$ and zeolite. 1. Unstabilized plastigel, 2. 2.11\% $\mathrm{ZnSt}_{2}$, 3. 2.11\% zeolite, 4. $0.53 \% \mathrm{ZnSt}_{2}$ $+0.53 \%$ zeolite, 5. $1.05 \% \mathrm{ZnSt}_{2}+1.05 \%$ zeolite, 6. $1.56 \% \mathrm{ZnSt}_{2}+1.56 \%$ zeolite, 7. 2.07\% $\mathrm{ZnSt}_{2}+2.07$ zeolite.

\section{RESULTS AND DISCUSSION}

\section{Kinetic Study of PVC Plastigels}

The thermal degradation of PVC is substantially a twostep process. The first step mainly involves progressive unzipping of neighboring labile chlorine atoms along the polymer chain by heat [5]. The second step is the formation of double conjugated bonds as a result of continuous reactions according to the free radical mechanism. The fatty acid salt of metal (II) ion $\mathrm{M}$ (Ca (II) or $\mathrm{Zn}$ (II) for the present study) reacts with PVC by an esterifying displacement of chlorine (Eqs. 1, 2). Stabilization arises from substitution of labile chlorine atoms with more stable carboxylate groups. Unfortunately, the heat stability of these groups are limited and they can be removed from the molecules at high temperatures, therefore the degradation of PVC starts:

$\mathrm{M}(\mathrm{OOCR})_{2}$
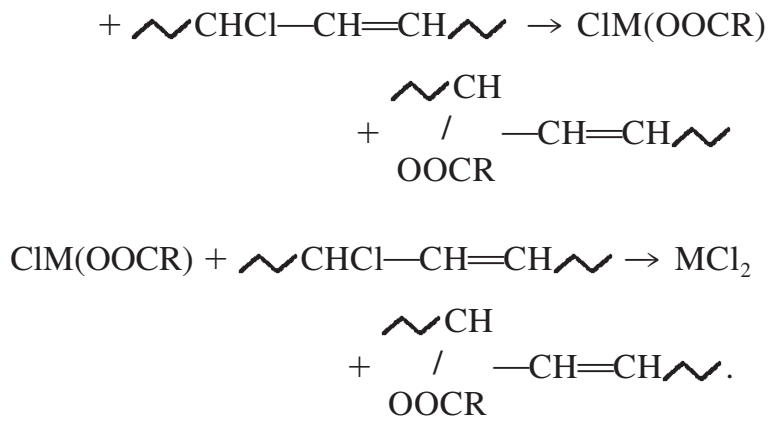

This process yields a corrosive gas, $\mathrm{HCl}$, and leads to highly reactive polyenes absorbing light in the UV and visible region [15]. The diffusion of $\mathrm{HCl}$ from the polymer to the medium might be slow or rapid, depending on whether the morphology of PVC plastigel is porous or not.

On the other hand, released $\mathrm{HCl}$ reacts with metal soaps, zinc or calcium stearate for the present study, and stearate anion is transformed into stearic acid (HSt). The reactions can be shown as:

$$
\begin{aligned}
& \mathrm{ZnSt}_{2}+\mathrm{HCl} \rightarrow \mathrm{ZnCl}_{2}+\mathrm{HSt} \\
& \mathrm{CaSt}_{2}+\mathrm{HCl} \rightarrow \mathrm{CaCl}_{2}+\mathrm{HSt}
\end{aligned}
$$

Since $\mathrm{ZnCl}_{2}$ is a Lewis acid, it also accelerates dehydrochlorination reaction after its concentration reaches above a critical value. For $\mathrm{CaCl}_{2}$ no acceleration effect is observed.

The induction time values measured by PVC Thermomat indicates the period when released $\mathrm{HCl}$ gas started to increase sharply and the period after the elimination of $\mathrm{HCl}$ from the samples was investigated as shown below.

In ohmic material the resistance is proportional to the resistivity $(\rho)$ measured in $\Omega . c m$ (in SI units $\Omega . \mathrm{m}$ ). Its inverse $\mathrm{K}=\Omega^{-1} \mathrm{~cm}^{-1}$ is the conductivity. The unit of conductance is the Siemens $\left(\mathrm{S}=\Omega^{-1} \mathrm{~cm}^{-1}\right)$. Conductivity of an electrolyte solution depends on the number density of charge carriers (number of electrons z) and how fast they can move in the material (mobility $\mathrm{U}$ ), concentration of the solution, and the Faraday constant, so the conductivity can be found by the Eq. 5:

$$
K=F \cdot \Sigma\left|Z_{i}\right| \cdot C_{i} \cdot U_{i}
$$




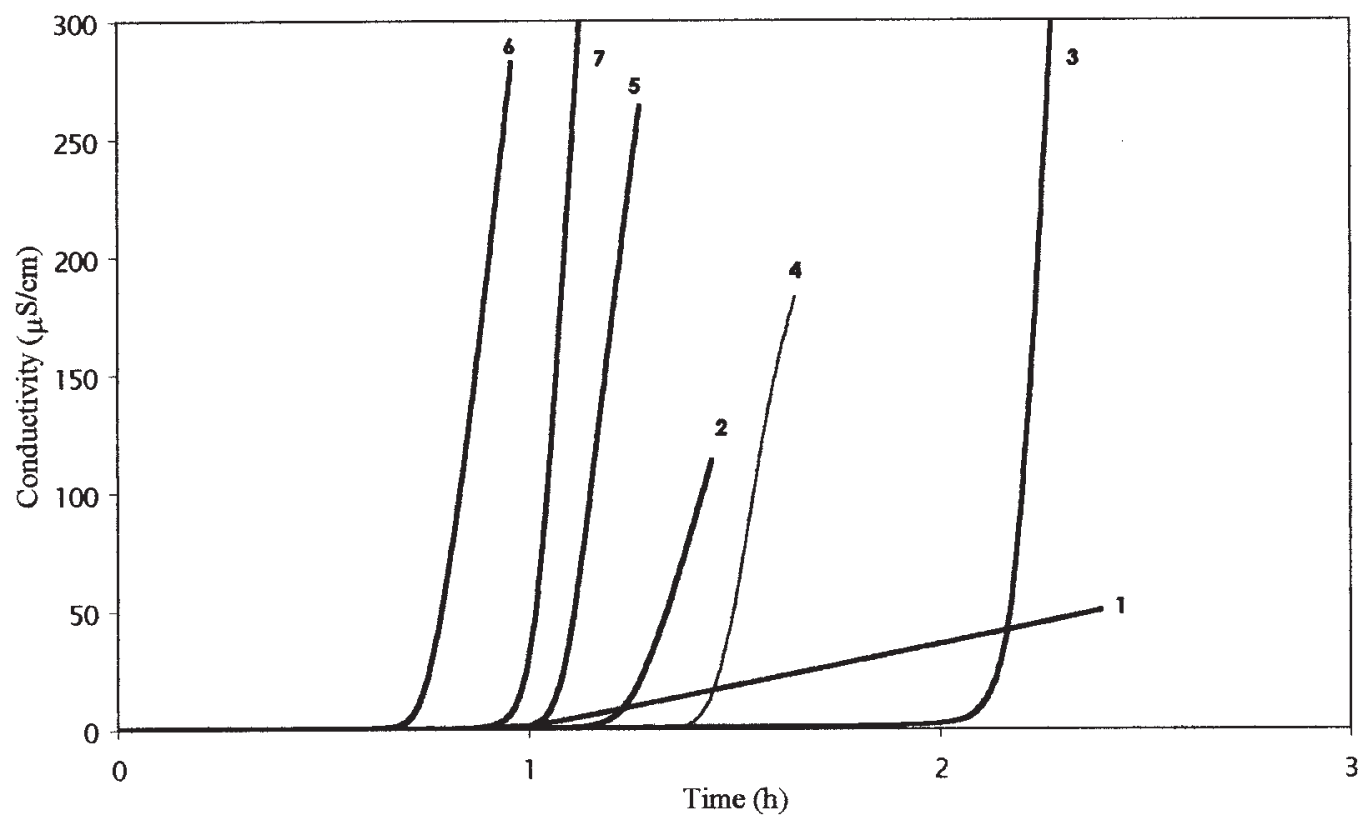

FIG. 3. The change of conductivity of aqueous solution with respect to time at $160^{\circ} \mathrm{C}$ for PVC plastigels stabilized with $\mathrm{ZnSt}_{2}$ and zeolite. 1. Unstabilized plastigel, 2. 2.11\% $\mathrm{ZnSt}_{2}$, 3. 2.11\% zeolite, 4. 0.53\% $\mathrm{ZnSt}_{2}+0.53 \% \mathrm{zeolite}$, 5. $1.05 \% \mathrm{ZnSt}_{2}+1.05 \%$ zeolite, 6. $1.56 \% \mathrm{ZnSt}_{2}+1.56 \%$ zeolite, 7. 2.07\% $\mathrm{ZnSt}_{2}+2.07$ zeolite.

where $\mathrm{F}=96485(\mathrm{C} / \mathrm{mol}) ;\left|\mathrm{Z}_{\mathrm{i}}\right|=$ Total charge number; $\mathrm{C}_{\mathrm{i}}$ $=$ Concentration of the solution $\left(\mathrm{mol} / \mathrm{m}^{3}\right) ; \mathrm{U}_{\mathrm{i}}=$ Mobility of ions $\left(\mathrm{m}^{2} / \mathrm{V} . \mathrm{s}\right)$. Mobility of ions $\left(\mathrm{U}_{\mathrm{i}}\right)$ dissolved in water is the sum of electric mobilities of $\mathrm{H}^{+}$and $\mathrm{Cl}^{-}$ions at $25^{\circ} \mathrm{C}$ for aqueous $\mathrm{HCl}$ [16].

$$
\begin{aligned}
U_{H} & =36.25 * 10^{-8}\left(\frac{\mathrm{m}^{2}}{\mathrm{~V} \cdot \mathrm{s}}\right) \\
U_{C l} & =7.913 * 10^{-8}\left(\frac{\mathrm{m}^{2}}{\mathrm{~V} \cdot \mathrm{s}}\right) \\
U_{H C l} & =44.163 * 10^{-8}\left(\frac{\mathrm{m}^{2}}{\mathrm{~V} \cdot \mathrm{s}}\right)
\end{aligned}
$$

The curves which show the conductivity change with respect to time were used to determine the rate constant of dehydrochlorination of any sample. The slopes $(a)$ of these curves were related to the rate of change of the conductivity $(K)$ with respect to time of the solution. The concentrations of the solutions were evaluated by the help of $E q$. 5. Thus, the rate of dehydrochlorination of PVC was determined by using the amount of $\mathrm{HCl}$ that transferred into the deionized water:

$$
a=\frac{\Delta K}{\Delta t}
$$

The conductivity of an electrolyte solution is the sum of the contributions of all the ionic species in the electrolyte (Eq. 5).

When the dehydrochlorination of PVC is taken as a first-order reaction [5]:

\begin{tabular}{|c|c|c|c|c|c|}
\hline \multicolumn{2}{|c|}{ Additive mass $\%$} & \multirow{2}{*}{$\begin{array}{l}\text { Induction } \\
\text { time (h) }\end{array}$} & \multirow{2}{*}{$\begin{array}{l}\text { Stabilization } \\
\text { time (h) }\end{array}$} & \multirow{2}{*}{$\begin{array}{c}\text { Initial rate } \\
\text { constant } k_{i} \times 10^{6} \\
\quad\left(\min ^{-1}\right)\end{array}$} & \multirow{2}{*}{$\begin{array}{c}\text { Linear region rate } \\
\text { constant } k_{1 r} \times \\
10^{4}\left(\mathrm{~min}^{-1}\right)\end{array}$} \\
\hline $\mathrm{ZnSt}_{2}$ & Zeolite & & & & \\
\hline- & - & 9.00 & 14.95 & 1.62 & 0.04 \\
\hline 2.11 & - & 6.50 & 13.59 & 35.15 & 2.64 \\
\hline- & 2.11 & 13.00 & 22.73 & 1.22 & 1.37 \\
\hline 0.53 & 0.53 & 6.00 & 9.36 & 9.98 & 1.12 \\
\hline 1.05 & 1.05 & 6.40 & 6.63 & 9.48 & 1.22 \\
\hline 1.56 & 1.56 & 4.50 & 4.77 & 12.34 & 1.38 \\
\hline 2.07 & 2.07 & 4.70 & 4.92 & 46.51 & 2.87 \\
\hline
\end{tabular}

$$
\mathrm{PVC}(\mathrm{s}) \rightarrow \operatorname{dePVC}(\mathrm{s})+\mathrm{HCl}(\mathrm{g})
$$

TABLE 2. Induction, stabilization time values, and rate constants at $140^{\circ} \mathrm{C}$ for $\mathrm{PVC}$ plastigels stabilized with $\mathrm{ZnSt}_{2}$ and zeolite. 


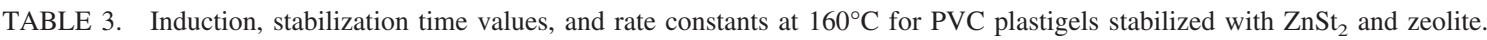

\begin{tabular}{|c|c|c|c|c|c|}
\hline \multicolumn{2}{|c|}{ Additive mass $\%$} & \multirow{2}{*}{$\begin{array}{l}\text { Induction } \\
\text { time }(\mathrm{h})\end{array}$} & \multirow{2}{*}{$\begin{array}{l}\text { Stabilization } \\
\text { time (h) }\end{array}$} & \multirow{2}{*}{$\begin{array}{c}\text { Initial rate } \\
\text { constant } k_{i} \times 10^{5} \\
\left(\min ^{-1}\right)\end{array}$} & \multirow{2}{*}{$\begin{array}{c}\text { Linear region rate } \\
\text { constant } k_{1 r} \times \\
10^{4}\left(\min ^{-1}\right)\end{array}$} \\
\hline $\mathrm{ZnSt}_{2}$ & Zeolite & & & & \\
\hline- & - & 1.01 & 2.39 & 0.93 & 0.17 \\
\hline 2.11 & - & 1.15 & 1.34 & 12.89 & 4.51 \\
\hline- & 2.11 & 2.10 & 2.17 & 4.22 & 2.84 \\
\hline 0.53 & 0.53 & 1.25 & 1.50 & 6.90 & 6.20 \\
\hline 1.05 & 1.05 & 1.05 & 1.11 & 17.51 & 6.59 \\
\hline 1.56 & 1.56 & 0.70 & 0.79 & 26.54 & 7.95 \\
\hline 2.07 & 2.07 & 0.95 & 1.02 & 18.80 & 16.60 \\
\hline
\end{tabular}

where dePVC $=$ dehydrochlorinated PVC. The rate of dehydrochlorination depends on concentration of potential double bonds or concentration of unreacted $\mathrm{HCl}$ in $\mathrm{PVC}$ :

$$
\frac{d C_{H C l}}{d t}=k \cdot\left(C_{o}-C_{H C l}\right)
$$

where $\frac{d C_{H C l}}{d t}=$ Rate of dehydrohlorination $(\mu \mathrm{mol} / \mathrm{gr} \mathrm{PVC}$. $\mathrm{s}) ; \mathrm{k}=$ Rate constant of the reaction $\left(\mathrm{s}^{-1}\right) ; C_{o}=$ Potential double bonds to be formed when $100 \%$ of $\mathrm{HCl}$ is eliminated per $1 \mathrm{~g}$ of PVC; $C_{o}=16.5 \times 10^{3} \mu \mathrm{mol} / \mathrm{g} . \mathrm{PVC} ; C_{H C l}$ $=$ Concentration of evolved $\mathrm{HCl}$ from the sample.

When 1 mole $\mathrm{HCl}$ is eliminated, 1 mole double bond forms. Since $C_{\mathrm{HCl}}<<<C_{o}, C_{o}-C_{H C l}$ can be taken as 16.5 $\times 10^{3} \mu \mathrm{mol} / \mathrm{g} . \mathrm{PVC}$.

$$
\frac{d C_{H C l}}{d t}=k \cdot C_{o}
$$

$\frac{d C_{H C l}}{d t}$ can be calculated from the slope of conductivity versus time graph by taking the derivative of Eq. $I$ with respect to time.

$$
\frac{d K}{d t}=F \cdot \Sigma\left|Z_{i}\right| \cdot \frac{d C_{H C l, w}}{d t} \cdot U_{H C l}
$$

where $C_{H C l, w}$ is the concentration of $\mathrm{HCl}$ in water.

Assuming all $\mathrm{HCl}$ evolved from PVC was absorbed by water,

$$
\frac{d C_{H C l, w}}{d t} \cdot V_{w}=\frac{d n_{H C l}}{d t}
$$

where $n_{H C l}=$ Moles of evolved $\mathrm{HCl}$ gas; $V_{w}=$ Volume of water in measuring vessel; $V_{w}=6 \times 10^{-5} \mathrm{~m}^{3}$.

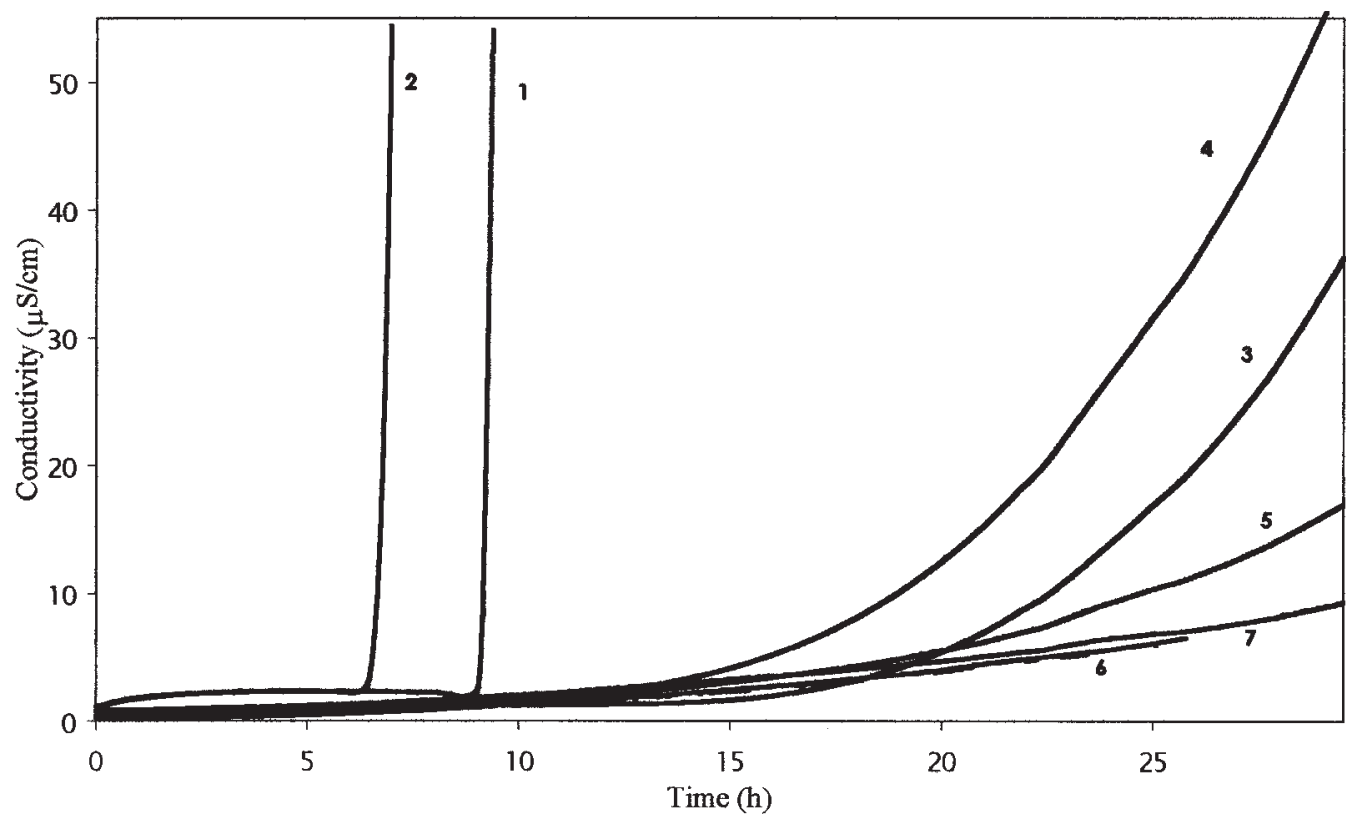

FIG. 4. The change of conductivity of aqueous solution with respect to time at $140^{\circ} \mathrm{C}$ for PVC plastigels stabilized with $\mathrm{CaSt}_{2}$ and zeolite. 1. Unstabilized plastigel, 2. 2.11\% $\mathrm{CaSt}_{2}, 3.2 .11 \%$ zeolite, 4. $0.53 \% \mathrm{CaSt}_{2}+0.53 \%$ zeolite, 5. $1.05 \% \mathrm{CaSt}_{2}+1.05 \%$ zeolite, 6. $1.56 \% \mathrm{CaSt}_{2}+1.56 \%$ zeolite, 7. $2.07 \% \mathrm{CaSt}_{2}+2.07$ zeolite. 


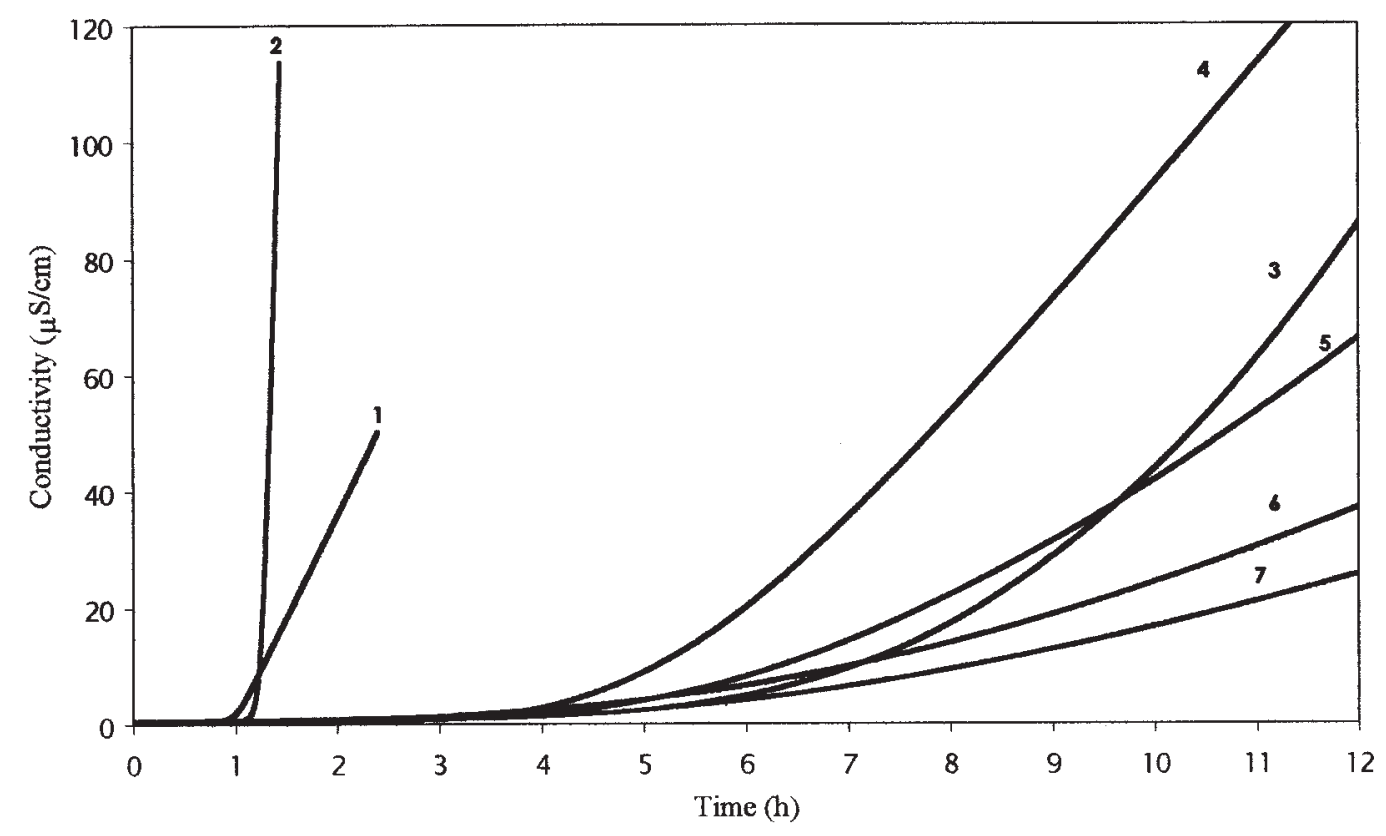

FIG. 5. The change of conductivity of aqueous solution with respect to time at $160^{\circ} \mathrm{C}$ for $\mathrm{PVC}$ plastigels stabilized with $\mathrm{CaSt}_{2}$ and zeolite. 1. Unstabilized plastigel, 2. $2.11 \% \mathrm{CaSt}_{2}, 3.2 .11 \%$ zeolite, 4. $0.53 \% \mathrm{CaSt}_{2}+0.53 \%$ zeolite, 5. $1.05 \% \mathrm{CaSt}_{2}+1.05 \%$ zeolite, 6. $1.56 \% \mathrm{CaSt}_{2}+1.56 \%$ zeolite, 7. $2.07 \% \mathrm{CaSt}_{2}+2.07$ zeolite.

$$
\frac{d C_{H C l}}{d t}=\frac{d n_{H C l}}{d t} \cdot \frac{1}{m \cdot C F}
$$

where $m=$ Mass of plastisol in reaction vessel; $C F=$ Fraction of PVC in PVC plastisol.

$$
k=\frac{d C_{H C l}}{d t} \cdot \frac{1}{C_{o}}=\frac{d n_{H C l}}{d t} \cdot \frac{1}{m \cdot C F} \cdot \frac{1}{C_{o}}
$$

Two rate constants were calculated for each dehydrochlorination reaction. Initial rate constants $\left(\mathrm{k}_{\mathrm{i}}\right)$ were determined by using the initial region of the curves where $\mathrm{HCl}$ gas started to evolve, and linear region rate constants $\left(\mathrm{k}_{\mathrm{lr}}\right)$ were evaluated by using the linear region of the curve where the acceleration effect of $\mathrm{HCl}$ and the products formed at the end of dehydrochlorination on degradation process could be observed.

The kinetic study was performed not only to investigate the thermal degradation of PVC and PVC plastigels but also to see the effect of addition of metal soaps and zeolite on dehydrochlorination of PVC at 140 and $160^{\circ} \mathrm{C}$ by $\mathrm{PVC}$ Thermomat. This instrument was tested with the same PVC samples to validate the accuracy and the results were identical for each sample at $160^{\circ} \mathrm{C}$. It was observed that, first, the conductivity values for all the samples were constant, in other words, $\mathrm{HCl}$ was not evolved from the PVC plastigels; thereafter, dehydrochlorination of $\mathrm{PVC}$ occurred and $\mathrm{HCl}$ started to evolve and changed the conductivity of the aqueous solution. Therefore, the induction time is the period up to inflection point of this curve.

PVC plastigels were tested at 140 and $160^{\circ} \mathrm{C}$. Figures 2 and 3 show the change of conductivity of aqueous solution with respect to time for PVC plastigels stabilized with $\mathrm{ZnSt}_{2}$ and zeolite at two different temperatures. Also, the induction, stability periods, and the rate constants of dehydrochlorination which were computed from the slopes of the

\begin{tabular}{|c|c|c|c|c|c|}
\hline \multicolumn{2}{|c|}{ Additive mass $\%$} & \multirow{2}{*}{$\begin{array}{l}\text { Induction } \\
\text { time (h) }\end{array}$} & \multirow[b]{2}{*}{$\begin{array}{l}\text { Stabilization } \\
\text { time (h) }\end{array}$} & \multirow{2}{*}{$\begin{array}{c}\text { Initial rate } \\
\text { constant } k_{i} \times 10^{7} \\
\quad\left(\min ^{-1}\right)\end{array}$} & \multirow{2}{*}{$\begin{array}{c}\text { Linear region rate } \\
\text { constant } k_{1 r} \times \\
10^{6}\left(\mathrm{~min}^{-1}\right)\end{array}$} \\
\hline $\mathrm{CaSt}_{2}$ & Zeolite & & & & \\
\hline- & - & 9.00 & 14.95 & 16.20 & 3.87 \\
\hline 2.11 & - & 15.00 & $>26$ & 5.27 & 2.80 \\
\hline - & 2.11 & 13.00 & 22.73 & 12.20 & 13.74 \\
\hline 0.53 & 0.53 & 10.00 & 28.39 & 3.78 & 2.75 \\
\hline 1.05 & 1.05 & 5.00 & $>26$ & 1.32 & 0.73 \\
\hline 1.56 & 1.56 & 4.00 & $>26$ & 2.63 & 2.64 \\
\hline 2.07 & 2.07 & 5.00 & $>26$ & 0.04 & 0.32 \\
\hline
\end{tabular}

TABLE 4. Induction, stabilization time values, and rate constants at $140^{\circ} \mathrm{C}$ for PVC plastigels stabilized with CaSt $\mathrm{Ca}_{2}$ and zeolite. 
TABLE 5. Induction, stabilization time values, and rate constants at $160^{\circ} \mathrm{C}$ for $\mathrm{PVC}$ plastigels stabilized with $\mathrm{CaSt} \mathrm{and}_{2}$ zeolite.

\begin{tabular}{|c|c|c|c|c|c|}
\hline \multicolumn{2}{|c|}{ Additive mass $\%$} & \multirow{2}{*}{$\begin{array}{l}\text { Induction } \\
\text { time (h) }\end{array}$} & \multirow{2}{*}{$\begin{array}{l}\text { Stabilization } \\
\text { time (h) }\end{array}$} & \multirow{2}{*}{$\begin{array}{c}\text { Initial rate } \\
\text { constant } k_{i} \times 10^{7} \\
\left(\min ^{-1}\right)\end{array}$} & \multirow{2}{*}{$\begin{array}{c}\text { Linear region rate } \\
\text { constant } k_{1 r} \times \\
10^{6}\left(\min ^{-1}\right)\end{array}$} \\
\hline $\mathrm{CaSt}_{2}$ & Zeolite & & & & \\
\hline- & - & 1.01 & 2.39 & 93.12 & 17.27 \\
\hline 2.11 & - & 7.00 & 22.35 & 3.52 & 14.81 \\
\hline - & 2.11 & 2.10 & 2.17 & 421.55 & 284.18 \\
\hline 0.53 & 0.53 & 4.00 & 7.82 & 44.30 & 8.86 \\
\hline 1.05 & 1.05 & 4.50 & 10.77 & 23.97 & 6.59 \\
\hline 1.56 & 1.56 & 4.00 & 13.78 & 4.53 & 7.46 \\
\hline 2.07 & 2.07 & 4.00 & 16.57 & 8.05 & 3.22 \\
\hline
\end{tabular}

kinetic curves are shown in Tables 2 and 3. The sample stabilized with $2.11 \%$ zeolite presents a longer induction time $(13 \mathrm{~h})$ than the others at $140^{\circ} \mathrm{C}$ due to the neutralization of the produced $\mathrm{HCl}$ by zeolite. Also, it has the highest stability time $(22.73 \mathrm{~h})$, as shown in Table 2 . The rapid dehydrochlorination after $13 \mathrm{~h}$ for the sample stabilized with zeolite can be explained by the saturation of $\mathrm{HCl}$ capacity of zeolite according to some authors [12]. When $2.11 \% \mathrm{ZnSt}_{2}$ was used to stabilize the PVC plastigel, it neither delayed the induction time nor decreased the rate of dehydrochlorination. Induction time was decreased from $9.00 \mathrm{~h}$ to $6.50 \mathrm{~h}$ and stability time decreased $14.95 \mathrm{~h}$ to $13.59 \mathrm{~h}$. At low $\mathrm{ZnSt}_{2}$ and zeolite levels at $140^{\circ} \mathrm{C}$, the synergism between these heat stabilizers on thermal degradation of PVC was observed due to the slow dehydrochlorination of $\mathrm{PVC}$, as shown by the low linear region rate constant. As $\mathrm{ZnSt}_{2}$ amount in PVC plastisol was increased, the linear region rate constant increased accordingly.

At $160^{\circ} \mathrm{C}$ all the samples were thermally degraded in $3 \mathrm{~h}$, as shown in Fig. 3. The induction periods of the sample decreased with increasing temperature. Also, the amount of $\mathrm{HCl}$ evolved from the samples seemed to be higher than previously, since it got up to more than $295 \mu \mathrm{S} / \mathrm{cm}$. The sample which was unstabilized had the lowest rate constants for initial and linear regions. When zeolite was the only stabilizer at $160^{\circ} \mathrm{C}$, it showed a stabilizing effect by increasing the induction and stability periods. Induction time increased from $1.01 \mathrm{~h}$ to $2.10 \mathrm{~h}$. This effect was considered to result from the absorption of $\mathrm{HCl}$, which catalyzed the dehydrochlorination of PVC. Zeolite captured catalytic, highly mobile $\mathrm{HCl}$ before elimination of further $\mathrm{HCl}$ occurred. But when the $\mathrm{HCl}$ capacity of zeolite was not sufficient to absorb the evolved $\mathrm{HCl}$, the acid catalyzed the degradation reaction by evolving from the sample. Therefore, zeolite provided a long induction period, but it did not prevent or decrease the rate of dehydrochlorination of PVC. Nevertheless, it had lower rate constants than the samples having $\mathrm{ZnSt}_{2}$.

Figures 4 and 5 show the conductivity of aqueous solution with respect to time for PVC plastigels stabilized with $\mathrm{CaSt}_{2}$ and zeolite at 140 and $160^{\circ} \mathrm{C}$. The induction, stability periods, and the calculated rate constants from the kinetic curves are reported in Tables 4 and 5. Unlike $\mathrm{ZnCl}_{2}$, alkaline earth chloride did not promote dehydrochlorination. At $160^{\circ} \mathrm{C}$, the stabilization time was increased with the increasing amount of $\mathrm{CaSt}_{2}$. Additionally, the samples stabilized with both $\mathrm{CaSt}_{2}$ and zeolite had better stabilizing effects than the sample stabilized with $\mathrm{CaSt}_{2}$ individually.

\section{Activation Energies of Dehydrochlorination Reactions}

The change of rate constant with temperature is represented by the Arrhenius equation as:

$$
k=A \cdot e^{-E / R \cdot T}
$$

where $k=$ Rate constant; $A=$ Preexponential factor; $E$ $=$ Activation energy $(\mathrm{j} / \mathrm{mole}) ; R=$ Gas constant $(8.314$ $\mathrm{J} / \mathrm{mole} . \mathrm{K}$ ); and $T=$ Absolute temperature (K). The activation energy was determined experimentally by carrying out the reaction at two different temperatures $\left(140\right.$ and $\left.160^{\circ} \mathrm{C}\right)$ :

$$
\ln \frac{k_{2}}{k_{1}}=-\frac{E}{R} \cdot\left(\frac{1}{T_{2}}-\frac{1}{T_{1}}\right)
$$

For the dehydrochlorination of unstabilized sample, the activation energy values were calculated as 129.70 and $111.27 \mathrm{~kJ} / \mathrm{mole}$ for initial and linear region. As shown in Tables 6 and 7, the activation energy values at linear region are generally lower than the values at initial region for all the samples due to the high rate of dehydrochlorination of PVC after the consumption of stabilizers and acceleration effect of the evolved acid. When zeolite was used as a

TABLE 6. Activation energies of initial and linear regions of the kinetic curves for the samples stabilized with $\mathrm{ZnSt}_{2}$ and zeolite.

\begin{tabular}{lcccc}
\hline \multirow{2}{*}{ Additive mass \% } & & \multicolumn{2}{c}{ Activation energy $(\mathrm{kj} / \mathrm{mole})$} \\
\cline { 5 - 5 } $\mathrm{ZnSt}_{2}$ & Zeolite & & Initial region & Linear region \\
\hline- & - & & 129.72 & 107.41 \\
2.11 & - & & 96.46 & 39.75 \\
- & 2.11 & & 263.05 & 54.16 \\
0.53 & 0.53 & & 143.53 & 127.02 \\
1.05 & 1.05 & & 216.47 & 125.21 \\
1.56 & 1.56 & & 227.77 & 129.99 \\
2.07 & 2.07 & 103.69 & 130.28 \\
\hline
\end{tabular}


TABLE 7. Activation energies of initial and linear regions of the kinetic curves for the samples stabilized with $\mathrm{CaSt}_{2}$ and zeolite.

\begin{tabular}{lcccc}
\hline \multirow{2}{*}{ Additive mass \% } & & \multicolumn{2}{c}{ Activation energy $(\mathrm{kj} / \mathrm{mole})$} \\
\cline { 5 - 5 } $\mathrm{CaSt}_{2}$ & Zeolite & & Initial region & Linear region \\
\hline & & & 129.72 & 107.41 \\
2.11 & - & & 29.96 & 123.65 \\
- & 2.11 & & 262.97 & 53.95 \\
0.53 & 0.53 & & 182.70 & 86.85 \\
1.05 & 1.05 & & 215.21 & 163.33 \\
1.56 & 1.56 & & 40.20 & 77.11 \\
2.07 & 2.07 & 393.77 & 171.39 \\
\hline
\end{tabular}

primary stabilizer, it not only increased the induction period, but also increased the activation energy at initial region. Although the sample stabilized with $2.11 \% \mathrm{ZnSt}_{2}$ presented higher activation energy than the sample having $2.11 \% \mathrm{CaSt}_{2}$ for initial region, the activation energy of this sample was lower for linear region due the acceleration effect of the produced $\mathrm{ZnCl}_{2}$ on the second step of dehydrochlorination of PVC in Tables 6 and 7. The sample stabilized with both $\mathrm{ZnSt}_{2}$ and zeolite (except $2.07 \% \mathrm{ZnSt}_{2}$ and $2.07 \%$ zeolite) clearly indicated the high activation energy values for linear region as compared with unstabilized PVC plastigel due to the ability of zeolite to absorb $\mathrm{HCl}$, reducing further acid-catalyzed dehydrochlorination of PVC.

The PVC plastigel stabilized with $2.07 \% \mathrm{ZnSt}_{2}$ and $2.07 \%$ zeolite presented highest activation energy values for linear region in Table 6. Neither of the samples stabilized with $\mathrm{ZnSt}_{2}$ nor zeolite individually got up to these values. Therefore, the rate of dehydrochlorination of PVC was reduced by increasing the activation energy of this reaction.

\section{Preexponential Factors of Dehydrochlorination Reactions}

Preexponential factors (A) of initial and linear regions of the kinetic curves for PVC plastigels were evaluated by using Eq. 17. These values are reported in Tables 8 and 9. Activation energy (E) and preexponential factor values are very different from each other, while the

TABLE 8. Preexponential factor of PVC plastigels stabilized with $\mathrm{ZnSt}_{2}$ and zeolite.

\begin{tabular}{|c|c|c|c|}
\hline \multicolumn{2}{|c|}{ Additive mass $\%$} & \multirow{2}{*}{$\begin{array}{l}\text { Initial region } \\
\text { preexponential } \\
\text { factor }\end{array}$} & \multirow{2}{*}{$\begin{array}{l}\text { Linear region } \\
\text { preexponential } \\
\text { factor }\end{array}$} \\
\hline $\mathrm{ZnSt}_{2}$ & Zeolite & & \\
\hline- & - & $4.15 \times 10^{10}$ & $3.63 \times 10^{7}$ \\
\hline 2.11 & - & $5.57 \times 10^{7}$ & 16.49 \\
\hline- & 2.11 & $2.27 \times 10^{27}$ & 468.51 \\
\hline 0.53 & 0.53 & $1.42 \times 10^{13}$ & $2.36 \times 10^{11}$ \\
\hline 1.05 & 1.05 & $2.27 \times 10^{22}$ & $1.55 \times 10^{11}$ \\
\hline 1.56 & 1.56 & $7.95 \times 10^{23}$ & $6.63 \times 10^{11}$ \\
\hline 2.07 & 2.07 & $6.05 \times 10^{7}$ & $1.50 \times 10^{12}$ \\
\hline
\end{tabular}

TABLE 9. Preexponential factor of PVC plastigels stabilized with $\mathrm{CaSt}_{2}$ and zeolite.

\begin{tabular}{|c|c|c|c|}
\hline \multicolumn{2}{|c|}{ Additive mass $\%$} & \multirow{2}{*}{$\begin{array}{l}\text { Initial region } \\
\text { preexponential } \\
\text { factor }\end{array}$} & \multirow{2}{*}{$\begin{array}{c}\text { Linear region } \\
\text { preexponential } \\
\text { factor }\end{array}$} \\
\hline $\mathrm{CaSt}_{2}$ & Zeolite & & \\
\hline- & - & $4.26 \times 10^{10}$ & $4.27 \times 10^{8}$ \\
\hline 2.11 & - & $2.16 \times 10^{-3}$ & $1.22 \times 10^{10}$ \\
\hline- & 2.11 & $2.22 \times 10^{27}$ & 91.42 \\
\hline 0.53 & 0.53 & $4.85 \times 10^{16}$ & $2.65 \times 10^{5}$ \\
\hline 1.05 & 1.05 & $2.19 \times 10^{20}$ & $3.32 \times 10^{14}$ \\
\hline 1.56 & 1.56 & 0.03 & $4.13 \times 10^{3}$ \\
\hline 2.07 & 2.07 & $2.54 \times 10^{41}$ & $1.26 \times 10^{16}$ \\
\hline
\end{tabular}

reaction rate constants in the same region are close to each other since the reactions follow different mechanisms. In order to confirm these results, kinetic compensation effect was investigated by plotting $\ln A$ vs. E curves as shown in Figs. 6 and 7. Linear relation between activation energy and preexponential values were observed for both initial and linear regions. The equations of the lines for the samples having $\mathrm{ZnSt}_{2}$ and zeolite are:

$$
\begin{aligned}
& \ln A=0.28 E-9.67 \text { (initial region) } \\
& \ln A=0.27 E-9.95 \text { (linear region). }
\end{aligned}
$$

The equations of the lines for the samples having $\mathrm{CaSt}_{2}$ and zeolite are:

$$
\begin{aligned}
& \ln A=0.2818-13.588 \text { (initial region) } \\
& \ln A=0.281-11.761 \text { (linear region). }
\end{aligned}
$$

These equations are consistent with the equations found by other authors [17, 18]. This linear relation shows the kinetic compensation effect confirming dehydrochlorination occurs with different mechanisms with different stabilizers.

\section{CONCLUSIONS}

Measurements in PVC Thermomat gave information about the release of $\mathrm{HCl}$ from the PVC plastigels to the surroundings. At $160^{\circ} \mathrm{C}$ the results indicated that the addition of metal soaps or zeolite to PVC plastisol increased the induction time, since this period for unstabilized PVC plastigel was $1.01 \mathrm{~h}$, whereas the induction periods for samples having $\mathrm{ZnSt}_{2}$ or $\mathrm{CaSt}_{2}$ or zeolite were $1.15,7$, and $2.1 \mathrm{~h}$, respectively. The sample stabilized with only $2.11 \% \mathrm{CaSt}_{2}$ presented the longest period since alkaline earth chloride did not promote dehydrochlorination. The stabilizing effect of zeolite on the increase in the induction period of the sample was considered to be the result of the absorption of $\mathrm{HCl}$, which was thought to reduce the autocatalytic effect of $\mathrm{HCl}$ evolved at the 


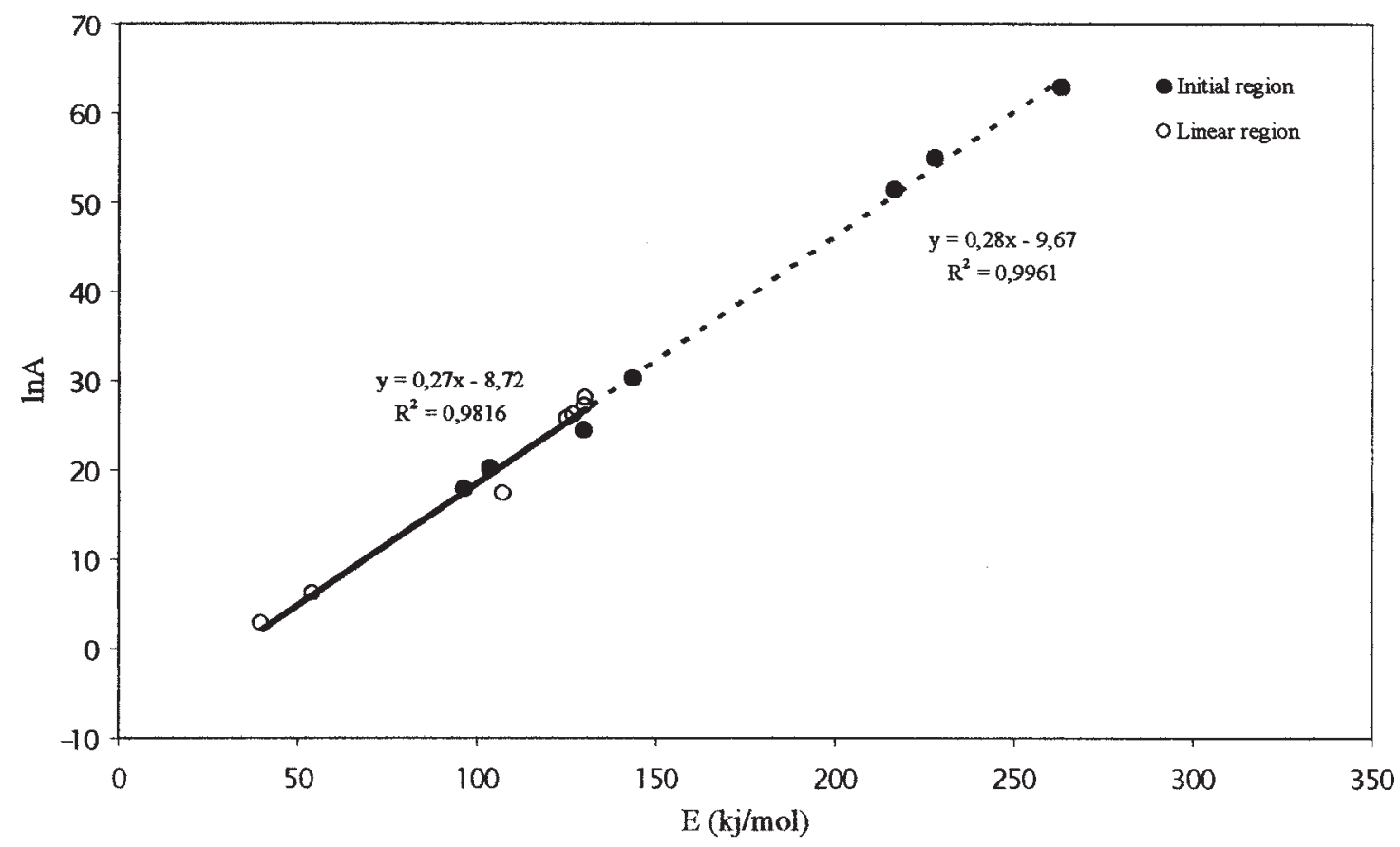

FIG. 6. Kinetic compensation effect curve for the samples having $\mathrm{ZnSt}_{2}$ and zeolite.

initial stages of dehydrochlorination. When $\mathrm{ZnSt}_{2}$ and zeolite were used together at $160^{\circ} \mathrm{C}$, the maximum induction time of $1.25 \mathrm{~h}$ was recorded for the sample having $0.53 \% \mathrm{ZnSt}_{2}$ and $0.53 \%$ zeolite. Additionally, the samples stabilized with $\mathrm{CaSt}_{2}$ and zeolite had a longer induction period than the unstabilized sample. Also, the maximum induction time was determined as $4.5 \mathrm{~h}$ for the sample having $1.05 \% \mathrm{CaSt}_{2}$ and $1.05 \%$ zeolite. Fur- thermore, the linear relation between the activation energy and preexponential factor values confirmed kinetic compensation effects for the dehydrochlorination reactions.

Unless $\mathrm{HCl}$ gas is released from PVC plastigels to the surroundings, PVC Thermomat will not give any information about the dehydrochlorination reaction. Also, the thickness and porous structure of the films affects the diffusion of

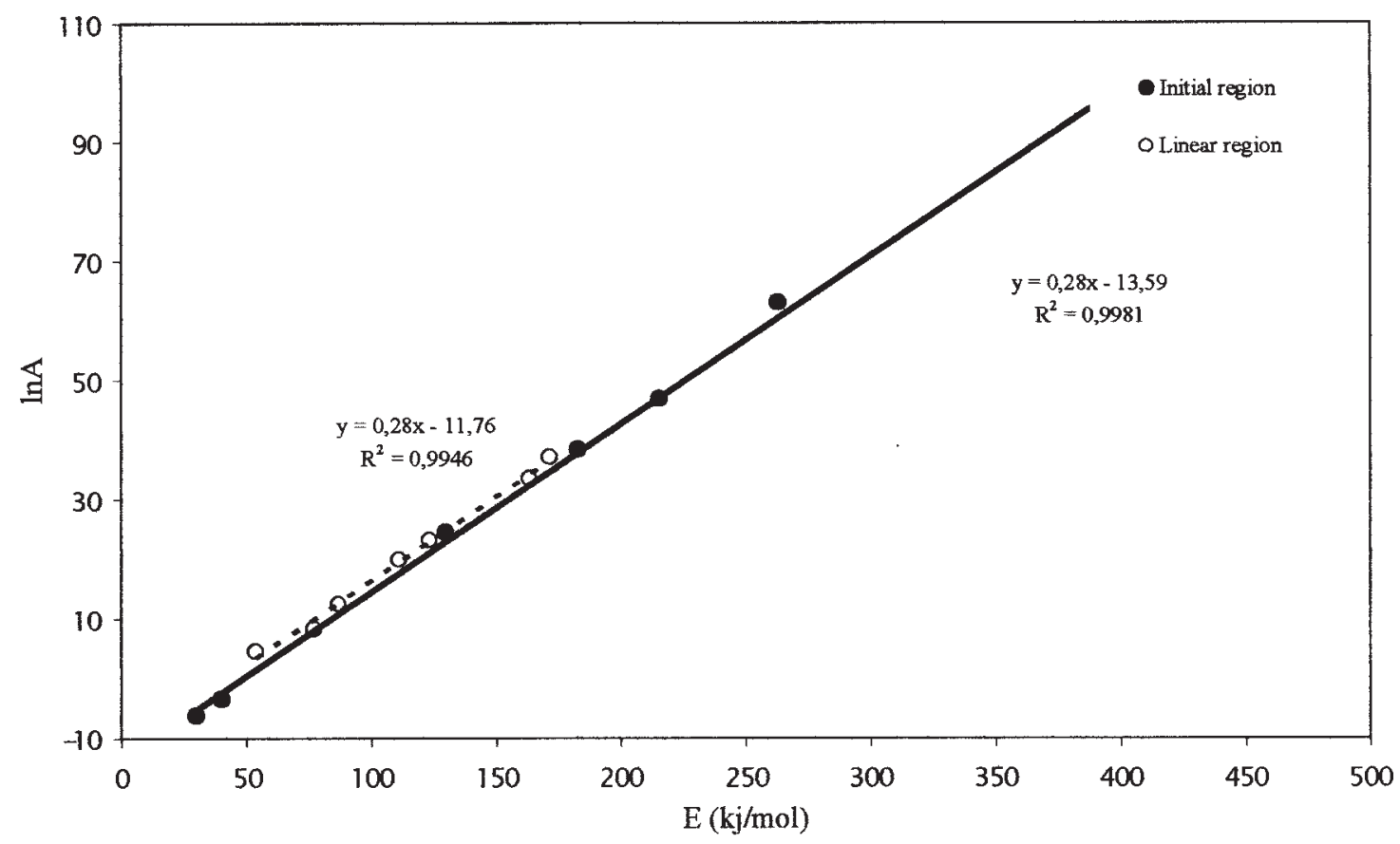

FIG. 7. Kinetic compensation effect curve for the samples having $\mathrm{CaSt}_{2}$ and zeolite. 
$\mathrm{HCl}$ gas from the films to the surroundings, so diffusion of $\mathrm{HCl}$ through PVC plastigels will be studied in future work. Additionally, the potential thermal stabilizers such as chabazite and mordenite could also be investigated in the same study.

\section{REFERENCES}

1. N.S. Vrandečić, I. Klarić, and U. Roje, Polym. Degrad. Stab., 74, 203 (2000).

2. A. Jiménez, L. Torre, and J.M. Kenny, Polym. Degrad. Stab., 73, 447 (2001).

3. M. Beltrán, J.C. Garcia, and A. Marcilla, Eur. Polym. J., 33, 453 (1997).

4. H. Baltacioğlu and D. Balköse, J. Appl. Polym. Sci., 74, 2488 (1999).

5. W.V. Titow, PVC Technology, Elsevier Applied Science Publishers, London and New York (1985).

6. H. İ. Gökçel, D. Balköse, and U. Köktürk, Eur. Polym. J., 35, 1501 (1999).

7. S. Hollande and J-L. Laurnt, Polym. Degrad. Stab., 55, 141 (1997).
8. R. Benavides, B.M. Castillo, A.O. Castañeda, G.M. López, and G. Arias, Polym. Degrad. Stab., 73, 417 (2001).

9. M.T. Benaniba, N.B. Bensemra, and G. Gelbard, Polym. Degrad. Stab., 82, 245 (2003).

10. A.H. Frye and R.W. Host, J. Polym. Sci., 40, 419 (1961).

11. R.F. Grossman, J. Vinyl. Addit. Technol., 6, 4 (2000).

12. L.V.D. Ven, V.M.L.M. Gemert, L.F. Batenburg, J.J. Keern, L.H. Gielgens, T.P.M. Koster, and H.R. Fischer, Appl. Clay. Sci., 17, 25 (2000).

13. M. Gönen, "Process Development for Metal Soaps," M.Sc. Thesis, Department of Chemical Engineering, İzmir Institute of Technology, İzmir, Turkey (2003).

14. A. Top and S. Ülkü, Appl. Clay. Sci., 27, 13 (2004).

15. A. Jiménez, L. Torre, and J.M. Kenny, J. Therm. Anal. Cal., 61, 483 (2000).

16. R.A. Alberty, Physical Chemistry, John Wiley \& Sons, Canada (1987).

17. M.C. Gupta and S.G. Viswanath, Ind. Eng. Chem., 37, 2707 (1998).

18. E. Arkis, "Lead Free PVC Heat Stabilizers," Ph.D. Thesis, Department of Chemical Engineering, Ege University, İzmir, Turkey (2000). 